\title{
EL PENSAMIENTO POLÍTICO DE JOSÉ GAOS. LA CRÍTICA DEL TOTALITARISMO*
}

\author{
ANTOLÍN SÁNCHEZ CUERVO \\ Instituto de Filosofía CSIC
}

\begin{abstract}
RESUMEN: Se revisan diversos escritos de José Gaos, escasamente conocidos y muchos de ellos aún inéditos, relacionados con el ámbito de la política en el amplio sentido del término. Tal fue el caso de algunas reflexiones motivadas por el protagonismo global de la guerra, el totalitarismo y la tecnocracia en los modos de vida actuales, incluyendo aquellos que son característicos de las sociedades democráticas occidentales. Al hilo de este protagonismo, Gaos planteó una revisión genealógica del proceso secularizador de la racionalidad moderna, que conectará con algunas de sus grandes preocupaciones, como la posibilidad de la filosofía como tal y del pensamiento de lengua española en particular.
\end{abstract}

PALABRAS CLAVE: José Gaos, política, totalitarismo, publicidad, técnica, secularización.

\section{The political Thought of José Gaos. The Criticism of Totalitarianism}

ABSTRACT: Jose Gaos's diverse writings are reviewed, many of them scantily known and still unpublished, related to the area of the politics in the wide sense of the term. It was the case of some reflections motivated by the global protagonism of the war, the totalitarianism and the technocracy in the current manners of life, including those that are typical of the democratic western companies. In line with this protagonism, Gaos raised a genealogical review of the secularizing process of modern rationality, which will connect with some of his big worries, such as the possibility of the philosophy itself and the possibility of the Hispanic philosophy especially. KEY WORDS: José Gaos, politics, totalitarianism, publicity, technology, secularization.

\section{1. ¿GaOs, EL POLÍtico?}

José Gaos (1900-1969) fue un intelectual poliédrico, de múltiples y diversas facetas, todas ellas muy meritorias: temprano receptor de la fenomenología en España, de la mano de García Morente y Zubiri ${ }^{1}$; principal discípulo de Ortega en el

La presente contribución ha sido realizada en el marco del proyecto de investigación El pensamiento del exilio español de 1939 y la construcción de una racionalidad política (FFI2012-30822), financiado por el Ministerio de Economía y Competitividad del Gobierno de España.

1 Cfr. Gaos, J., Introducción a la fenomenología seguida de La crítica al psicologismo en Husserl, Ed. de Agustín Serrano de Haro, Encuentro, Madrid, 2007. La crítica del psicologismo en Husserl había sido su tesis doctoral, defendida en 1928 en la Universidad Central de Madrid bajo la dirección de Xavier Zubiri. La Introducción a la fenomenología había sido su memoria de oposición a cátedra presentada en dicha universidad, en 1930 y -de nuevo y de manera exitosa, a la cátedra de Introducción a la filosofía- en 1933. Sobre la obra fenomenológica posterior de Gaos, cfr. ColoneLLo, P., Entre fenomenología y filosofía de la existencia. Ensayo sobre José Gaos, Morelia, Jitanjáfora, 2006; Llano Cifuentes, C., Ensayos sobre José Gaos: metafísica y fenomenología, UNAM, México, 2008 . 
horizonte de la Escuela de Madrid² y, sin solución de continuidad, uno de los principales filósofos del exilio republicano español del 39 y también de los más influyentes en el México de la segunda mitad del $\mathrm{XX}^{3}$; impulsor de la filosofía mexicana y latinoamericana, y de lo que suele reivindicarse como un "pensar en español», tanto por sus proyectos historiográficos como por su reflexión acerca del tema autor de la primera traducción de Sein und Zeit a una lengua occidental'; erudito tanto del pensamiento clásico como del contemporáneo, con los que nunca dejó de dialogar, e historiador consecuente de la filosofía —o de «nuestra idea del mundo», tal y como denominó a su extenso curso de 1966, editado póstumamente ${ }^{6}$; practicante de la «filosofía de la filosofía», como asimismo gustaba decir apropiándose de una célebre expresión de Dilthey, en un horizonte de crisis radical y de amenaza a la misma supervivencia de la filosofía ${ }^{7}$; autor de libros sistemáticos ${ }^{8}$ y hasta reformador de la Universidad... ${ }^{9}$ Las facetas intelectuales de Gaos son por tanto muy diversas, incluso si nos limitamos a las más significativas, como es el caso ${ }^{10}$.

2 Cfr. Abellán, J. L., Historia crítica del pensamiento español. La crisis contemporánea. De la gran guerra a la guerra civil española (1914-1939), tomo 5 (III), Espasa Calpe, Madrid, 1991, pp. 229-323; Serrano de Haro, A., "Prólogo" a Gaos, J., Obras completas I. Los escritos españoles, UNAM, México (en prensa).

3 Cfr Valero Pie, A., José Gaos en México: una biografía intelectual, 1938-1969, El Colegio de México, México, 2015.

4 Cfr. Gaos, J., Obras completas VI. Pensamiento de lengua española. Pensamiento español, Prólogo de José Luis Abellán, UNAM, México, 1990; Obras completas V. El pensamiento hispanoamericano. Antología del pensamiento de lengua española en la edad contemporánea. Prólogo de Elsa Cecilia Frost, UNAM, México, 1993; Obras completas VIII. Filosofía mexicana de nuestros días. En torno a la filosofía mexicana. Sobre la filosofía y la cultura en México, Prólogo de Leopoldo Zea, UNAM, México, 1996. Cfr. también Alfaro, H.G., El pensamiento de José Ortega y Gasset y José Gaos: una vertiente del pensamiento latinoamericano, UNAM, México, 1992; Muguerza, J., "Ortega en Latinoamérica: el legado filosófico de José Gaos”, en SÁnchez Cuervo, A.; Hermida de Blas, F. (Coords.), Pensamiento exiliado español. El legado filosófico del 39 y su dimensión iberoamericana, Biblioteca Nueva-CSIC, Madrid, 2012, pp. 56-81; mi apunte “José Gaos entre dos orillas”, en Daimon. Revista de Filosofía, Suplemento 2 (2008), pp. 385-390.

5 Cfr. el reciente trabajo de Stanton, A., "Martin Heidegger, traducido por José Gaos, en El arco y la lira de Octavio Paz”, en Sánchez Cuervo, A.; Zermeño Padilla (Eds.), El exilio español del 39 en México. Mediaciones entre mundos, disciplinas y saberes, El Colegio de México, México, 2014, pp. 101-116.

6 Cfr. Gaos, J., Obras completas IV. De Descartes a Marx. Estudios y notas de historia de la filosofía, Prólogo de Ramón Xirau, UNAM, México, 1997; Obras completas XIV. Historia de nuestra idea del mundo, Prólogo de Andrés Lira, 1994, UNAM, México, 1994.

7 Cfr. Gaos, J., Obras completas III. Ideas de la filosofía (1938-1959), Prólogo de Abelardo Villegas, UNAM, México, 2003; Obras completas VII. Filosofía de la filosofía e historia de la filosofía, Prólogo de Raúl Cardiel Reyes, UNAM, México, 1987.

8 Cfr. Gaos, J., Obras completas XII. De la filosofía (curso de 1960), Prólogo de Luis Villoro, UNAM, México, 1982; Obras completas XIII. Del hombre (curso de 1965), Prólogo de Fernando Salmerón, UNAM, México, 1992.

9 Cfr. Gaos, J., Obras completas XVI. La filosofía en la Universidad, Prólogo de Juliana González, UNAM, México, 2000.

10 Además de los libros apuntados en las notas anteriores, cfr., entre otros, AAVV, José Gaos. Una filosofía de la filosofía, en Anthropos. Revista de documentación científica de la cultura, $\mathrm{n}^{\circ} 130$ 131 (marzo-abril 1992); González di Pierro, E., José Gaos: historicismo y cultura en México, Jitanjáfora, Morelia, 2010; NaEssens, H., La concepción del hombre en José Gaos y Francisco Romero, Universidad Autónoma del Estado de México, México, 2011; SEvilla, S (ED.), Visiones sobre un 
Sin embargo, rara vez se ha hablado de un Gaos con inquietudes políticas, y no por casualidad o por una mera omisión. Ciertamente, puede resultar desconcertante hablar de filosofía política en el caso de un pensador que tanto se dedicara a sesudas meditaciones sobre el fundamento, el sentido, las paradojas y la legitimidad del filosofar, más cercanas a un perfil especulativo; o que acuñara el término «transtierro» para identificar la experiencia de su exilio, despojándola así de su inmenso potencial crítico en tanto que figura capaz de cuestionar radicalmente muchos de los espacios y tiempos construidos por, para y desde la racionalidad moderna ${ }^{11}$.

Ahora bien, Gaos entendió siempre el oficio del filósofo bajo el imperativo de la responsabilidad y el compromiso ante los problemas de su tiempo, de la incorporación reflexiva a la acción colectiva histórica y no como una tarea especulativa sin más. No olvidemos que, al menos por una coincidencia cronológica - y seguramente por algo más-, Gaos no dejaba de inscribirse en la generación de 1930, caracterizada, precisamente, por un marcado compromiso con la acción cívica ante los nuevos tiempos que se avecinaban en el ocaso de la dictadura de Primo de Rivera ${ }^{12}$. De hecho, Gaos se adhirió a la defensa de la II República desde su instauración en 1931 y, si bien se mostró siempre muy reacio a las luchas partidistas y a las pugnas por el poderío político, se afilió al Partido Socialista Obrero Español de la mano de Fernando de los Ríos, lo cual nos da una idea, por cierto, de su perfil ideológico: un socialismo "ético», entendido en términos de un reformismo decidido pero nunca radicalizado, ligado a los valores laicos y universalistas de la educación republicana; un socialismo distante del marxismo que respeta el ámbito de la persona, las libertades individuales y el relativismo intelectual; que advierte las contradicciones entre los imperativos de la justicia social y la lógica del capitalismo, y que rechaza cualquier dogmatismo. En definitiva, un socialismo en términos un tanto difusos, comunes a cierto liberalismo y característico de cierto pensamiento político español contemporáneo, a menudo muy ligado al institucionismo ${ }^{13}$. El propio Gaos reivindicará esta suerte de «liberalismo socialista» o «socialismo liberal» más de dos

transterrado. Afán de saber acerca de José Gaos, Iberoamericana-Vervuert, Madrid-Frankfurt, 2008; Sevilla, S.; Vázouez, M. E. (Eds.), Filosofía y vida. Debate sobre José Gaos, Biblioteca Nueva, Madrid, 2012; YamunI, V., José Gaos. El hombre y su pensamiento, UNAM, México, 1980.

11 Lo he planteado en mi trabajo "Fuera de lugar, a destiempo. El exilio como figura política", en Aguirre, A.; Sánchez Cuervo, A.; Roniger, L. Tres estudios sobre el exilio. Condición humana, experiencia histórica y significación política, EDAF-BUAP, Madrid-Puebla, 2014, pp. 107-193. Cfr. la crítica de otro filósofo del exilio republicano español del 39 en México como Adolfo Sánchez Vázquez, por ejemplo en "Del destierro al transtierro", en Alted, A.; Llusia, M. (Dirs.), La cultura del exilio republicano español de 1939 (2 vol), UNED, Madrid, 2003, vol. II, pp. 627-640; también VALERo PIE, A., "Metáforas del exilio: José Gaos y su experiencia del 'transtierro", en Revista de Hispanismo Filosófico, no 18 (2013), pp. 71-87.

12 Jesús Moreno Sanz sintetiza este compromiso generacional a propósito de María Zambrano, en el primer capítulo de "Estudio introductorio. La política desde su envés histórico-vital: historia trágica de la esperanza y sus utopías", en Zambrano, M., Horizonte del liberalismo, Madrid, Morata, 1996, pp. 13-56. El propio Gaos evoca ese mismo ambiente en Obras completas XVII. Confesiones profesionales. Aforística, Prólogo de Vera Yamoni, UNAM, México, 1982, pp. 100-107.

13 Quizá el mejor ejemplo sea El sentido humanista del socialismo (Morata, Madrid, 1926) de Fernando de los Ríos, libro emblemático, además, de la Generación del 14. Cfr. la edición crítica de Jacobo Muñoz en Biblioteca Nueva, Madrid, 2006. También podría ser representativo el primer libro de María Zambrano, Horizonte de Liberalismo, asimismo publicado por la editorial Morata, en 1930. Cfr. la edición crítica de Jesús Moreno Sanz, en esta misma editorial, en 1996. 
décadas después, en sus aforismos de 1960-62. Escritos en plena guerra fría y en un contexto en el que el marxismo gozaba de prestigio intelectual, Gaos expresará en ellos su distancia tanto del capitalismo como del comunismo, así como su postura a favor de una conciliación de las libertades y los derechos consignados bajo la tradición liberal con la exigencia de justicia social. «Es duro» - anotará en este sentido el 28 de octubre de 1960 — «tener que tomar partido por la justicia social o por el liberalismo, pero yo no puedo tomar partido más que por la justicia social con liberalismo o por el liberalismo con justicia social» ${ }^{14}$. Asimismo —escribirá el 4 de diciembre de 1961- «Si el comunismo va a liberalizarse y el capitalismo a socializarse, no hay por qué renegar del liberalismo socialista o del socialismo liberal, y si ni lo uno ni lo otro - menos» ${ }^{15}$. Ese mismo año, el 13 de enero, anotaría también:

«La verdad es que no puedo estar con el capitalismo ni con el comunismo. El capitalismo mantiene a millones de trabajadores del mundo entero en condiciones de vida inhumana en beneficio injustamente excesivo de la minoría de poseedores de la mayoría de las acciones de las grandes compañías internacionales. El comunismo mantiene a millones de hombres bajo el terror de hacérseles la vida imposible si piensan u obran, no políticamente en contra, sino simplemente en desacuerdo con las consignas culturales» ${ }^{16}$.

Pero, volviendo a los años republicanos, Gaos evocaría en sus Confesiones profesionales de 1958 la llamada del "deber» de incorporarse a "la acción colectiva con que los hombres concurrimos a los designios de la historia» cuando se proclamó la II República, y su militancia en el partido socialista por su carácter «sesudo» y «respetable», palpable en «la grave educación cívica que había dado a la mayoría de los obreros y los campesinos españoles (...)», y en «la conducta austera de sus dirigentes y sensata de sus masas... ${ }^{17}$. En todo caso, será con el inicio de la guerra que el discreto pero indudable compromiso cívico de Gaos con su tiempo se explicite del todo. De hecho, se alistará, al parecer, como voluntario de tropa, si bien no llegará a combatir en el frente al ser requerido para otro tipo de tareas. En concreto, la rectoría de la Universidad Central, de cuya evacuación será responsable, y la presidencia de la Junta Delegada de Relaciones Culturales de España con el Extranjero. Como tal, recorrerá diversos foros europeos, en Francia, Holanda, Suecia y Noruega, en los que reclamará apoyo internacional para la República española, explicando, sin demasiado éxito, los fundamentos políticos y jurídicos de su legitimidad, la dimensión internacional del conflicto español y la desigualdad de condiciones impuesta por el comité de no intervención. También será el responsable del pabellón español instalado en la Feria Internacional de París en 1937, en el que se expondrá por primera vez el Guernica de Picasso, y análogas reivindicaciones hará el año siguiente durante un curso impartido en la Universidad de La Habana ${ }^{18}$.

De los escritos gaosianos de esos años destaca una colaboración enviada a la emblemática revista republicana Hora de España. El texto en cuestión, inédito

14 Obras completas XVII, p. 238.

15 Ibid., p. 245.

16 Ibid., p. 240.

17 Ibid., p. 102.

18 Aurelia VALERo Pie recorre con detalle estos y otros episodios de Gaos durante los años de la guerra en el primer capítulo de José Gaos en México, pp. 25-50. 
hasta la fecha, comprendía trece páginas encabezadas por el título «Para Hora de España. Consideraciones para la política de la República» ${ }^{19}$. Allí definía las ideas de Marx en términos de un «realismo humanista», crítico hacia «la deshumanización» y «el materialismo del régimen capitalista», y plasmado en «un libro de filosofía moral de la historia» más que "de economía» ${ }^{20}$ como El Capital; y mostraba su rechazo hacia la orientación «escolástica» del marxismo, el cual había tomado a su juicio la filosofía de Marx "por verdadera en absoluto» ${ }^{21}$ desde Engels hasta Lenin. Nada más lejano de esta pretensión o de este "marxismo ortodoxo» ${ }^{22}$, en realidad "poco marxista» ${ }^{23}$ y sí muy ideológico, que el historicismo que por entonces Gaos ya hacía suyo y conforme al que «ninguna filosofía es más verdadera en general que las demás», habiendo de "concebir la verdad de forma que pueda dar razón de esta igualdad de todas las filosofías en ella ${ }^{24}$. Para Gaos, Marx era sin duda un filósofo eminente, pero su filosofía no era ni más ni menos verdadera que las demás. Por eso su adhesión a la causa de la justicia social, según explicaba él mismo durante los años de la guerra, pasaba necesariamente por la militancia en un partido obrero, pero no necesariamente marxista.

En todo caso, el interés de Gaos por Marx no será precisamente insignificante, aun sin llegar a alcanzar la relevancia del que mostrara por otros filósofos contemporáneos. De hecho, Gaos se había distinguido, ya antes de la guerra, por ser uno de los primeros profesores universitarios en el ámbito iberoamericano, en considerar la obra temprana de Marx desde un punto de vista académico, equiparándola a la de otros filósofos incorporados al canon. Estimulado por la publicación de sus escritos juveniles en $1932^{25}$, Gaos se había propuesto una traducción de diversos textos de Marx precedido de un largo ensayo sobre su obra, lo cual no dejaba de ser novedoso. La guerra había abortado este proyecto, que Gaos retomará muy poco tiempo después de llegar a México, al hilo de un seminario programado en la UNAM y con la motivación añadida de que el volumen sería publicado por Fondo de Cultura Económica. Sin embargo, el proyecto se frustró debido a la escasez de alumnos en el mencionado seminario y, si bien la Universidad Veracruzana se ofreció a retomarlo en 1958, para entonces Gaos se sentía desfasado: habían pasado dos décadas, con la II Guerra Mundial y los comienzos de la guerra fría de por medio, el interés por la obra de Marx había crecido en todos los sentidos y, en medio de múltiples compromisos académicos, no era posible actualizar aquel viejo proyecto. Habría que esperar a la edición póstuma de sus Obras completas para incluir aquellos materiales en el vol. IV, dedicado a estudios y notas de historia de la filosofía ${ }^{26}$.

19 Cf. Fondo documental del Dr. José Gaos, UNAM, Instituto Investigaciones Filosóficas, Fondo 2 , carpeta 1 , folios 30127-30138. Se trata de un texto manuscrito, sin fecha pero muy probablemente de 1937-38, años en los que se editó la emblemática revista republicana. Durante ese periodo se publicaron veintidós números, en cuyos sumarios no consta ningún artículo de José Gaos.

20 «Para Hora de España. Consideraciones para la política de la República». Fóleo 30134.

21 Ibid., folio 30135.

22 Ibid., folio 30131.

23 Ibid., folio 30134.

24 Ibid., folio 30133.

25 Cfr. Landshut, S.; Mayer, J. P., Der historische Materialismus. Die Frühschriften, Kröner Verlag, Leipzig, 1932.

26 Obras completas $I V$, pp. 457-585. 
Ahora bien, ello no impidió que el pensamiento de Marx siguiera presente en la actividad docente y profesional de Gaos. En 1962 le dedicaría parte de un curso sobre filosofía contemporánea impartido en la Universidad de Caracas ${ }^{27}$, mientras que en su curso sobre "historia de nuestra idea del mundo» impartido en El Colegio de México en 1966-67 incluiría cuatro lecciones dedicadas a «El marxismo y la filosofía», «El materialismo histórico y el dialéctico», "La economía y el socialismo» y «El comunismo y la Revolución» ${ }^{28}$. De 1968 data, en fin, «El juicio final del capitalismo», fruto de un seminario sobre El Capital impartido en ese mismo colegio el año anterior $^{29}$.

Se trata, en su conjunto, de largas exposiciones articuladas en torno a comentarios de textos - uno de los métodos preferidos de Gaos- y cuya interpretación puede resultar hasta cierto punto paradójica. Por una parte, y de manera predominante, el pensamiento de Marx se integra en la plural reacción contra la tradición metafísica, culminada y al mismo tiempo agotada en el idealismo de Hegel. Junto con el evolucionismo y el historicismo, el positivismo y la psicología científica, el voluntarismo o anti-racionalismo de Schopenhauer y Nietzsche, y el existencialismo o anti-esencialismo de Kierkegaard, el materialismo o anti-idealismo de Marx conformará una suerte de "nueva sofística» ${ }^{30}$ o "nuevo realismo humano» ${ }^{31}$ cuyo denominador común es el antropologismo y el irracionalismo. "Si el tema de la edad moderna fue el de la determinación de la realidad por la razón» —apuntará Gaos en su Historia de nuestra idea del mundo-, el de la edad contemporánea será el de la determinación de la razón por lo irracional» ${ }^{32}$.

Esta ubicación global de la obra de Marx no dejaba de ser un tanto peyorativa pues, si bien Gaos no apostó nunca por una rehabilitación de esa misma metafísica ya agotada, lo cual se antojaría ingenuo, tampoco se resignó a despedirla y desmitificarla sin más, en la línea de la crítica marxista, entre otras. Más bien buscaría una suerte de tercera vía, es decir, de reflexión tentativa sobre las posibilidades de la filosofía en tiempos post-metafísicos, de lo cual sería buena muestra su «filosofía de la filosofía», constante a lo largo de su exilio y culminante en sus libros más maduros y acabados: los ya citados De la filosofía y Del hombre. En ellos, recordemos, parte Gaos de una fenomenología de las expresiones verbales para extraer de ellas categorías racionales o conceptos fundamentales, cuyo carácter antinómico se resuelve en sentido kantiano, con una apelación a la razón práctica que sin embargo no se apoyará en un sujeto trascendental, sino en los motivos irracionales y las verdades personales de los sujetos empíricos. Es obvia la incompatibilidad entre este planteamiento, en el que alguna salida encuentra, aunque modesta, la razón filosófica, y la desmitificación sin concesiones de esta última realizada por Marx, lo cual le lleva a Gaos a afirmar que el marxismo «es la cuestión misma de la filosofía « ${ }^{33}$.

27 Cfr. Obras completas XI. Filosofía contemporánea. Un método para resolver los problemas de nuestro tiempo, Prólogo de Antonio Zirión, UNAM, México, 2007, pp. 125-175.

28 Se trata de las lecciones 6-9 de la segunda parte, dedicada a «La idea contemporánea y nuestra». Cfr. Obras completas XIV, pp. 531-606.

29 Cfr. , pp. 559-585.

$30 \quad$ Ibid., p. 456.

31 Ibid., p. 459.

32 Ibid., p. 459. Cf. también las pp. 456s.

33 Obras completas IV, p. 554. 
Ahora bien, como ya habíamos adelantado, Gaos también sugiere, aun de manera más puntual y escueta, una lectura de Marx en términos morales e incluso utópicos, en la medida en que su obra plantea todo un programa teórico de acción. Esa es la lectura que Gaos había esbozado en su escrito para Hora de España durante la guerra y también la que treinta años después desarrollará en «El juicio final del capitalismo». En esta ocasión, Gaos valorará de nuevo El Capital como a «un singularísimo libro de moral histórica» y no sólo «de pura teoría económica» ${ }^{34}$, en el que de hecho confluyen la crítica económica — tanto del régimen capitalista como de la ciencia económica clásica- y la crítica moral del servilismo y la crueldad que dicho régimen necesita generar para subsistir ${ }^{35}$.

Así pues, si por una parte Gaos se desmarca de los planteamientos de Marx en la medida en que niegan, supuestamente, la supervivencia de la razón filosófica, por otra reconoce el valor y alcance de su vocación moral. En ello radica su visión paradójica de este autor, de quien se desmarca en el ámbito de la razón teórica y con quien al mismo tiempo congenia en el de la razón práctica.

Pero, para entonces, para ese año de 1968 en que Gaos publicaba su trabajo sobre el juicio final del capitalismo, él ya había completado un largo exilio en México, a donde había llegado tempranamente, en 1938, como parte del primer contingente de profesores españoles exiliados, contratados por la recién creada Casa de España, más adelante denominada El Colegio de México. En realidad, ese exilio se había ido convirtiendo en "transtierro», según la exitosa expresión acuñada por el propio $\mathrm{Gaos}^{36}$, expresando con ello la creciente despolitización de su nuevo régimen de vida, entre otras cosas. Ciertamente, si dicho neologismo resultaba atinado para expresar la comunidad intelectual y de pensamiento entre España y México -y el resto de la llamada Hispanoamérica en definitiva- a la que el propio Gaos estaba contribuyendo con su labor académica y profesional, no lo era tanto para desahogar el potencial crítico y la dimensión política de la condición exiliada. Más bien al contrario, se trataba de un término que tendía a invisibilizar o sublimar la ruptura, el conflicto y hasta la barbarie inscritas en esa experiencia, o que en todo caso se adecuaba a cierto perfil de exilio, acomodado y estable, aun en medio de tantas penurias, como el del propio Gaos, quien finalmente gozó en todo momento de un status académico envidiable. Dicho de otra manera, se trataba de un término muy acorde con su creciente despolitización, favorecida por las severas restricciones de la legislación mexicana impuestas a los ciudadanos de origen extranjero para intervenir en la esfera pública, además de por su misma condición de derrotado y su tendencia hacia la meditación y el ensimismamiento académico. Esta tendencia, mayormente ligada al ámbito privado y al trabajo de escritorio, no hizo sino acentuarse, con el paso de los años, lo cual no debe confundirse con la indiferencia o la evasión apolítica. Consciente de que el silencio también podía ser una manera

34 Ibid., p. 565.

35 El marxismo como moral o como ética en el marco de una filosofía de la praxis y no sólo como una ciencia que, si bien persigue una interpretación objetiva de la realidad, no por ello cae en concepciones dogmáticas, deterministas u ontológicas, será desarrollado por el ya mencionado Adolfo SÁnchez VÁzouez. La primera versión de su Filosofía de la praxis (1967), era el resultado de su tesis doctoral en la UNAM, realizada bajo la dirección, precisamente, de José Gaos.

36 Cf. la nota 11. 
de hablar, Gaos se mantuvo firme y distante frente a los «cantos de sirena» que empezaban a llegar al exilio desde la España de Franco, secundados o no por el autodenominado "exilio interior». Gaos expresó con claridad, si bien en cartas y en escritos privados, su rechazo de cualquier mediación con la España de Franco e incluso de colaboración con sus intelectuales disidentes. En diversos momentos expresó su indignación ante la supuesta resignación, indolencia y fanatismo religioso de la sociedad española, así como ante el reconocimiento del régimen franquista por parte de la ONU, el Vaticano y los Estados Unidos. A su juicio, el fin de dicho régimen era condición de posibilidad de cualquier puente con el interior y no al contrario, lo cual explica su silencio frente al célebre artículo que Aranguen publicara en 1953 en Cuadernos hispanoamericanos sobre «La evolución espiritual de los intelectuales españoles en la emigración ${ }^{37}$, en el que se planteaba la necesidad de un acercamiento entre la España del exilio y la España del interior, o su negativa a publicar en revistas españolas, hasta los años sesenta ${ }^{38}$.

En todo caso, más allá de la circunstancia mexicana o española, más allá de vicisitudes nacionales e internacionales — aunque no de los problemas de su tiempo, que nunca dejaron de abonar la labor intelectual de Gaos-, cabe destacar su reflexión sobre el totalitarismo. Con ella, Gaos se ubicaba en ciertas coordenadas del pensamiento contemporáneo más actual.

\section{LA REFLEXIÓN SOBRE EL TOTALITARISMO}

A fin de cuentas, el detonante del largo y decisivo «transtierro» de José Gaos durante las tres décadas que median entre su salida hacia México en 1938 y su muerte en 1969, y que envuelve la mayor parte de su obra, no había sido otro, precisamente, que la experiencia totalitaria, cuya onda expansiva, flagrante en toda Europa, había llegado a España poniendo fin a la tradición intelectual de la que él mismo había formado parte. Bien es cierto que las alusiones de Gaos al totalitarismo a lo largo de su obra hasta ahora editada son puntuales y escuetas, encontrándose las más relevantes en sus notas sobre "Mi filosofía» de $1943^{39}$, en su libro Pensamiento de lengua española, publicado en $1945^{40}$, y en dos artículos aparecidos en 1946 bajo los títulos de «¿Son filosóficos nuestros días?» ${ }^{41}$ y «La situación de la filosofía en el momento presente ${ }^{42}$. Ahora bien, en algunos materiales todavía inéditos, las alusiones a esta cuestión son más profusas y significativas. Tal es el caso de diversos apuntes, esquemas y desarrollos incipientes, muchos de ellos fechados en diciembre de $1943^{43}$,

37 Cf. n ${ }^{\circ} 38$, pp. 123-158; también en Obras completas VI. Estudios literarios y autobiográficos, Trotta, Madrid, 1997.

38 Cf. el capítulo VII de Valero Pie, A., José Gaos en México, pp.179-207. También la carta de Gaos a su amigo García Bacca fechada el 21 de agosto de 1957, en Obras completas XIX. Epistolario y papeles privados, Prólogo de Alfonso Rangel Guerra, UNAM, México, 1999, pp. 407-412.

39 Cf. Obras completas III, pp. 395-433.

40 Cf. Obras completas VI, pp. 70 y 142-148.

41 Cf. Obras completas III, pp. 243-258.

42 Ibid., pp. 259-268.

43 Cf. Fondo documental del Dr. José Gaos, Fondo 1, carpeta 9B. UNAM. Instituto de Investigaciones Filosóficas. 
que bien podrían ser el esbozo de un libro nunca concluido, así como de un curso de metafísica impartido en $1944^{44}$, cuyo hilo conductor es el tránsito de la forma de vida propia del catolicismo a la forma de vida propia del inmanentismo moderno; algo que nos adelanta la principal clave genealógica gaosiana del totalitarismo, muy ligado, a su juicio, a la progresión secularizadora de la razón moderna.

Se trata por tanto de una constelación de escritos que datan de los primeros años del exilio mexicano de Gaos, cuando la experiencia de la guerra civil española es aún muy reciente y cuando su continuidad en la guerra que está asolando Europa tiene plena actualidad. Ciertamente, los escritos gaosianos relacionados con la experiencia vital, la delimitación conceptual y la génesis histórica del totalitarismo llevan la impronta de tan decisivos acontecimientos, los cuales obligan a una urgente tarea, muy presente, por lo demás, en no pocas reflexiones del pensamiento exiliado español de 1939: la supervivencia del logos y su rescate de las derivas opresivas, deshumanizantes y regresivas que han condicionado su evolución a lo largo de la Modernidad, hasta desembocar en la catástrofe actual. Junto a Gaos, otros compañeros de exilio como María Zambrano, Eugenio Ímaz, Eduardo Nicol, Joaquín Xirau asumirán estas derivas y pensarán a contrapelo de ellas, planteando respuestas a la altura de estos «tiempos oscuros». Remozarán el tópico del humanismo hispánico, entendido como una filosofía del ser humano construida a partir de su indigencia actual, mucho más que de planteamientos metafísicos o abstractos previos, bajo la presión de la guerra, el totalitarismo y la razón instrumental. Mucho más allá de un mero humanitarismo ${ }^{45}$.

En el caso de Gaos, la presencia del totalitarismo en su reflexión, lejos de ser eventual o de obedecer a motivos coyunturales, condiciona la pregunta por la filosofía misma. De hecho, una de las causas de la crisis que Gaos afronta como profesional de la filosofía no es otra, como él mismo reconoce, que su «radical impotencia contra el totalitarismo actual» ${ }^{46}$, al que no duda en definir como «el

44 Curso de metafísica de 1944. Fondo documental del Dr. José Gaos, Fondo 1, Carpeta 12, fóleos 1248-1599. Versión electrónica, capturada y cotejada a partir del manuscrito, por Antonio Zirión, a quien debo, además de a Sergio Sevilla y José Martínez Bisbal, la pista y el conocimiento de este curso. Según Antonio Zirión, coordinador de la edición de las Obras completas de José Gaos, dicho curso formará parte del tomo XVIII, actualmente en proceso de edición. De este curso existe además una versión editada en Toluca en 1993 por la Universidad Autónoma del Estado de México, pero con numerosos errores y erratas.

45 Lo he planteado en "Pensar contra la guerra. El humanismo del exilio republicano español de 1939”, en Aullón de Haro, P. (ed.): Teoría del humanismo (III). Verbum, Madrid, 2010, pp. $207-$ 230; "Umanesimo in tempi oscuri. J. Xirau, E. Imaz, E. Nicol, M. Zambrano", en Colonello, P.; SAntasilia, S. (EDS.), Intercultura, democrazia, societá. Per una societá educante, Mímesis, Milano, 2012, pp. 163-189.

46 "Mi filosofía», Obras completas III, p.395. En la p. 405 anota Gaos, en este mismo sentido, que "La filosofía se reveló crecientemente inoperante, impotente, ante los hechos históricos de nuestros días que encontraron su expresión extrema en el totalitarismo». Por otra parte, en este mismo ensayo se apuntan otras dos causas de dicha crisis. La primera sería el historicismo contemporáneo o el relativismo histórico en el que la filosofía parece naufragar cuando pretende fundamentarse a sí misma, cuestión que repetirá en numerosos lugares de su obra. La segunda sería el carácter insatisfactorio de la propia filosofía, ligado a la soberbia o la pretensión de dominio mediante el puro saber, frente al impulso hedonista de la vida. Las tres causas guardan relación entre sí, como más adelante veremos. 
fenómeno más patente, característico y típico » ${ }^{47}$, el «hecho histórico más relevante de nuestros días» y "el más decisivo», hasta el punto de que «la guerra actual» es su «manifestación extrema» ${ }^{48}$ y por lo tanto - expone sucintamente, haciéndose eco, quizá, de las tesis de Ernst Jünger y Carl Schmitt ${ }^{49}$ - algo determinado por su necesidad. La actualidad, la relevancia y el carácter primordial constituyen así la primera nota definitoria del totalitarismo según Gaos. «En la actualidad» -insiste- «nos encontramos los hombres en la situación fundamental de dependencia respecto de la guerra que se está sosteniendo». Fundamental, puesto que se trata de una situación que decide sobre todas las demás hasta el punto de someter a los hombres a «un nuevo régimen de vida, no sólo pública, sino privada y aun íntima, por la repercusión, siquiera, de la vida pública sobre la privada y sobre la íntima misma». Se trata por tanto de una beligerancia total, que acarrea la «esencial posibilidad constante de la muerte moral de la persona ${ }^{50}$, incluso - llega a apuntartras una previsible victoria de los aliados. ¿Por qué? ¿Por qué la amenaza totalitaria de esta muerte moral no se disiparía, necesariamente al menos, con una derrota del nazismo y una victoria de quienes supuestamente personificaban los valores democráticos y liberales madurados a lo largo de la modernidad occidental?

Plantear esta pregunta obliga, de entrada, a desprenderse de interpretaciones más o menos ingenuas del totalitarismo (¿cómo la de Ortega en La rebelión de las masas, por ejemplo, cuando lo reduce a una especie de gregarismo radicalizado, destructor de la cultura y las instituciones liberales, o a una especie de masificación del sujeto, previa renuncia a su autonomía responsable y abandono consecuente a inercias colectivas decadentes?) Y responderla, a dar un primer paso en la definición gaosiana de totalitarismo, por el que se podrían entender dos cosas. En primer lugar, en un sentido más o menos estricto y convencional, sería aquel régimen político, instaurado en Italia, Alemania, Rusia y otros "países menores que lo han imitado mejor o peor», caracterizado por la «determinación de la vida toda de los súbditos del Estado por éste» ${ }^{51}$. Es decir — decía en su inédito «La situación actual de beligerancia forzosa»-

«no sólo la vida pública toda, la vida política, económica, social, profesional, sino la vida privada e íntima toda, la profesional — que está señaladamente a

47 «El totalitarismo, 3/12/43». Texto manuscrito. Algunas páginas aparecen tachadas con dos líneas transversales. Fondo documental del Dr. José Gaos, Fondo 1, carpeta 9B, fóleo 899.

48 «La guerra, 17/12/43. Texto manuscrito. Ibid., fóleo 914. Asimismo, en uno de sus Fragmentos de dos exclusivas del hombre — sin fecha, pero muy probablemente de 1944_, sin aludir de una manera explícita al totalitarismo y la guerra, afirma lo siguiente: «Nuestros días son tremendos, con el temblor del temor por el dolor, dolor incluso de la muerte (...). Gigantescas masas humanas impelidas, sometidas a las más desgarradoras trasmigraciones, a las crueldades más aniquiladoras. Como no las había desde las épocas más catastróficas de la historia, desde la caída del Imperio romano de Occidente, las invasiones de los bárbaros, el fin del mundo antiguo (...)». Cf. Obras completas III, p. 211.

${ }_{49}$ El célebre ensayo de Carl Schmitt Der Begriff des Politischen (1932) había sido reseñado por un fino observador del nazismo, después exiliado también en México, como Eugenio Ímaz en Cruz y raya, 4 (julio de 1933), pp. 141-146.

50 «La situación actual de beligerancia forzosa». Texto manuscrito. Fondo documental del Dr. José Gaos, Fondo 1, carpeta 9B, fóleo 921a. El peligro de aniquilación de la persona bajo la amenaza totalitaria es referido por Gaos en una reseña del libro de Antonio CAso El peligro del hombre, publicada en 1942 en Filosofía y Letras. Cf. "Antonio Caso», Obras completas VI, pp. 142-148.

51 «El totalitarismo», fóleo 902. El término «toda» aparece subrayado. 
medias entre la pública y la privada-, la familiar, la sexual, hasta en puntos como la elección del cónyuge o la fidelidad al elegido, el tener o no hijos, la intimidad de la familia, entre solos padres e hijos, los íntimos pensamientos mismos en cuanto pueden espontánea, involuntariamente expresarse y ser conocidos o sospechosos por alguien (...)».

Bajo un régimen totalitario, todo ello llega a ser «asunto de Estado». Para ser más precisos, de

«un Estado de partido único u oficial, que quiere decir una parte de los súbditos erigidos en rectores, en dominadores exclusivos del resto; un Estado dictatorial, que quiere decir el partido único mismo, y a través de él el resto de los súbditos de ese estado, sujeto en instancia última a un jefe con autoridad de resolución personal irrestricta; un Estado policiaco, que quiere decir de hecho no sólo un cuerpo especial de inspección y pesquisa de la vida toda y de acción sobre ella, sino la extensión de estas funciones a todo el partido oficial y aun al resto de los súbditos, en función recíproca, hasta donde posible... Al "para" no le doy en la última frase en que figura ningún sentido de finalidad, sino un sentido de correlación funcional. -Esto es el totalitarismo- por lo pronto» ${ }^{52}$.

Gaos reparará especialmente en uno de los elementos que se dibujan en esta aproximación elemental: la pérdida de la intimidad o la "publicidad», característica además de otras formas de totalitarismo «avant la lettre», como las que pueden reconocerse en las «colectividades humanas primitivas», en "ciertos regímenes políticos del pasado, o de otras culturas que la occidental, y aun quizá en algunos puntos dentro de ésta, moderadamente (...)» ${ }^{53}$. Estos regímenes —apunta Gaos— «viven una vida exclusivamente colectiva. En ellas no hay vida privada ni íntima. Los individuos tienen sólo sentimientos e ideas comunes, colectivos, no propios: son menos "individuos"...», siendo "patente lo que entre esta vida y el totalitarismo hay de común». En este sentido, una "previa conversión del hombre en "público" fue condición de la determinación de su vida toda por el Estado, del totalitarismo» ${ }^{54}$. El hombre "no hubiera sido dominado en todos los sectores de la vida, hasta los privados e íntimos por el Estado, si él mismo no se hubiera vuelto previamente público ${ }^{55}$. Algo que, por lo demás, aparecerá muy ligado a otra condición fundamental del régimen totalitario, aun cuando las alusiones de Gaos a la misma en este contexto sean más escuetas: la «mecanización del hombre» o el «maquinismo ${ }^{56}$ — dirá a propósito de una visita realizada a una fábrica vidriera-, el «tecnicismo» o la «tecnocracia» ${ }^{57}$. Entre ambas

52 «La situación actual de beligerancia forzosa», fóleo 921a.

53 «El totalitarismo», fóleo 903. El término «avant la letre» aparece subrayado.

54 Ibid.

55 Curso de metafísica de 1944, p. 22.

56 «El totalitarismo», fóleo 903.

57 Tecnicismo, tecnocracia y otros términos muy semejantes están muy presentes en «Sobre la técnica» (1959) —un resumen de una parte de un curso impartido en 1942 en la Facultad de Filosofía de la UNAM bajo el título de «Metafísica de nuestra vida»-, en Obras completas XV. Discurso de filosofía. De antropología e historiografía. El siglo del esplendor en México, Prólogo de Álvaro Matute, México, 2009, pp. 306-314; y, sobre todo, en el capítulo «Tecnocracia y cibernética» incluido en la segunda parte del curso Historia de nuestra idea del mundo, impartido en 1966 y publicado por primera vez en 1973, en Obras completas XIV. Historia de nuestra idea del mundo. Nueva edición cotejada con el original y prólogo de Andrés Lira. UNAM, México, 1994, pp. 661-682. 
condiciones, entre «la "publicidad” " humana y la masa y la mecánica», hay «relaciones esenciales $»^{58}$.

Publicidad y tecnicismo dotan de hecho a la situación actual de guerra total y beligerancia forzosa de un carácter singular y desconocido hasta ahora. Si en las guerras antiguas - afirma Gaos- los contendientes «luchaban cuerpo a cuerpo, se reconocían individualmente, se interpelaban personalmente y la acción de los jefes era heroica o ejemplar en primera fila»; si los caballeros medievales, asimismo, «eran identificables por sus armas o adornos, emblemas y divisas» ${ }^{59}$, y en la edad moderna los diversos uniformes identificaban y distinguían a los ejércitos en los campos de batalla, en la guerra actual todo transcurre bajo el signo de la colectivización y la mecanización, del anonimato y el maquinismo. En nuestros días, guerra significa, no sólo una movilización sin precedentes que afecta también al conjunto de la población civil, sino también «reducción de la vida pública e íntima a la ocupación o la preocupación con el ataque y la defensa, en formas esencialmente mecanizadas y colectivas (...) $»^{60}$. Formas por medio de las cuales las masas humanas ya no se confunden, por el color de sus uniformes, con los elementos naturales, ni padecen el «terror todavía natural del aterrado y enterrado», sino que «se enmaquinan (sic), en máquinas que se acumulan en masas mecánicas que acaban empotrándose unas en otras y el terror es el extraterreno, el lunático del artificio maquinal $\aleph^{61}$.

Publicidad y tecnicismo constituyen así las dos grandes condiciones de posibilidad del estado totalitario, reforzándose entre sí y dotando a la guerra actual de un carácter hasta ahora desconocido.

Ahora bien, ambos rasgos —observa Gaos- no son sólo definitorios del estado totalitario en su acepción más convencional y beligerante, sino también del régimen de vida característico del estado liberal contemporáneo, dando pie a una nueva acotación conceptual del totalitarismo, más amplia, difusa e imprecisa, aunque al mismo tiempo más penetrante y de mayor profundidad crítica. El propio Gaos la adelantaba puntualmente en una cita anterior cuando aludía a su presencia «moderada» en algunos ámbitos de la cultura occidental. Ciertamente, publicidad y tecnicismo constituyen a su juicio rasgos definitorios de la vida contemporánea en su expresión más general, sin necesidad de discernir entre regímenes políticos concretos. En relación con el primero de estos rasgos, el propio curso de metafísica de 1944 encuentra algunos motivos de inspiración inmediatos en la «extrañeza (...) de que nuestro medio es un medio de totalitarismo, de publicidad, es decir, de invasión de la vida privada e íntima por la pública, que ha perdido el sentido de la intimidad y de sus derechos ${ }^{62}$.Por eso totalitarismo no es más que «el extremo de un movimiento anterior y mucho más ancho y radical: la creciente absorción de la vida privada e íntima por la pública; el movimiento que creo se puede llamar publicidad,

58 Fragmento manuscrito sin fecha, Fondo 2, carpeta 3, fóleo 30630. Debo a Aurelia Valero Pie el conocimiento de este texto.

59 «La situación actual de beligerancia forzosa», fóleo 922e.

60 "La guerra", fóleo 915. El término “vida pública e íntima” aparece subrayado.

61 Ibid., fóleo 922e.

62 Curso de metafísica de 1944, p. 2. 
la publicidad de la vida contemporánea» ${ }^{63}$, y cuyo radio de acción es mucho más amplio que el que pueda circunscribirse al fascismo, el nazismo y el comunismo.

Asimismo, la maquinización del hombre tampoco es exclusiva de la guerra actual, extendiéndose a todos los órdenes de la vida contemporánea. En este sentido, aun corriendo el riesgo de caer en un pequeño anacronismo, resulta muy pertinente apuntar en este contexto la reflexión que Gaos plasmará dos décadas después, en su Historia de nuestra idea del mundo, sobre la tecnocracia, entendida como «una dominación de la vida por la técnica, característica, distintiva, de nuestra vida, o nuestro mundo ${ }^{64}$, en un aspecto tanto cuantitativo — creciente sustitución de seres humanos por máquinas y artefactos_ como cualitativo — definición de la vida y de su sentido en función de la técnica-. De manera extrema en el caso de su expresión más actual, la cibernética, consistente tanto en la reducción de la comunicación a información esquematizada y capacitada para suplir los procesos humanos incluido el ámbito de las decisiones políticas, como en la circulación de la mayor cantidad de información en el menor tiempo posible. O como dirá el matemático estadounidense Norbert Wiener, supuesto creador del término «cibernética» en su libro Cybernetics or control and comunication in the animal and the machine (1948), a quien Gaos cita, el desarrollo de «un lenguaje y técnicas que nos permitan acometer efectivamente el problema de la regulación de las comunicaciones en general, y también encontrar el repertorio conveniente de ideas y técnicas para clasificar sus manifestaciones particulares según dichos conceptos» ${ }^{65}$. Para Gaos, ello implicará la universalización de algo que ya había advertido en su reflexión sobre la guerra totalitaria, como la sustitución del humano por la maquina o «la tesis de la importancia creciente de las máquinas para el hombre, de la maquinización, o mecanización, creciente del hombre: la tecnificación o tecnocracia, en cuanto la técnica es de máquinas, llevada a su colmo ${ }^{66}$. Por lo tanto, la erosión de algo tan vital para el ser humano como la comunicación, su despersonalización o -como reconoce Wiener- la clasificación de sus manifestaciones particulares conforme a lenguajes artificiales preestablecidos, lo cual significa prescindir de algo tan esencial en la comunicación como la singularidad de cada uno de sus mensajes o la irreductibilidad de cada palabra. Si lo relevante es la circulación esquematizada y más o menos homogénea de información, el resultado no puede ser otro que la informatización de las relaciones humanas, previa amputación, si es que no eliminación, de la expresión humana y, en definitiva, de su intimidad.

Cibernética significará entonces reemplazo de hombres por máquinas y devaluación de la comunicación en información. Pero también —apunta Gaos, siguiendo a Wiener - control político, tal y como revela la propia etimología del término, ligada a "gobernar», "gobierno» y «gubernamental», siendo equivalente al hipotético neologismo «gubernética», pues el griego «kybernétés» refiere al piloto de

63 Ibid., p. 15

64 Obras completas XIV, p. 662. La asimilación totalitaria del modelo científico-técnico característico del sistema de producción capitalista, y su extensión a la sociedad entera bajo la expresión de un "gran autómata» o un cuerpo maquinizado ha sido señalada por Claude LEFORT, entre otros. Cfr. La incertidumbre democrática. Ensayos sobre lo político, Edición de Esteban Molina, Anthropos, Barcelona, 2004, pp. 250s.

65 Ibid., p. 668.

66 Ibid., p. 667. 
una embarcación mientras que el verbo «kybernán» significa dirigir una embarcación. La regulación de mensajes en función de técnicas y códigos previamente calculados afecta así, no sólo a la esfera individual de la vida, sino también a su dimensión colectiva, a las relaciones sociales y la organización política de las mismas. En la medida en que la información abarca la cultura entera, la cibernética puede por tanto definirse «como una disciplina de universal —dominación: realmente gubernética por excelencia y eminencia. ¿Adonde llegará, ¿adonde prevé, quisiera llegar?» Gaos atisba una posible respuesta en el propio ensayo de Wiener, quien entrevé el potencial de la cibernética para dirigir, de una manera supuestamente racional, el conjunto de los procesos humanos, hasta el punto, incluso, de concebirse como "un aparato de aparatos de Estado, que cubriese el sistema entero de las decisiones políticas», alumbrando una «máquina de gobernar» capaz de suplir «la insuficiencia hoy patente de las cabezas y los aparatos habituales de la política» ${ }^{67}$. Así pues —apostilla Gaos- «una máquina de gobernar un Estado mundial, la máquina propiamente cibernética o gubernética, en vez de los políticos y los organismos y procedimientos tradicionales de la política». ¿No sería esto «la mecanización absoluta de la Humanidad» — se pregunta Gaos- el triunfo mecanicismo o del tecnicismo moderno «hasta el colmo de la anulación de lo humano en lo maquinal?» ${ }^{68}$.

Publicidad y tecnocracia, mutuamente entrelazadas, constituyen así, no sólo las condiciones de posibilidad del estado totalitario convencional, sino también las grandes señas de identidad del totalitarismo entendido como una forma de vida, capaz de subsistir bajo regímenes políticos demo-liberales, a cuyas expensas puede además legitimarse. Si publicidad es erradicación de la intimidad, vaciamiento del sujeto y reducción de la persona a su superficie pública y anónima, tecnocracia no será otra cosa que el control, el gobierno y la instrumentalización de esta subjetividad desposeída y masificada, su sacrificio en provecho de una dominación total y puramente funcional. Por eso afirmaba Gaos en su escrito de 1942 sobre la beligerancia forzosa actual, que no existen motivos decisivos para tomar partido por ninguno de los tres bandos en disputa durante la II Guerra Mundial, incluyendo el de los «británicos y anglosajones», pues este último también comporta rasgos totalitarios, aun cuando puedan convivir con una concepción liberal del Estado. No hay tales motivos, obviamente, a favor del nazismo y del comunismo soviético, cuyo régimen de publicidad, técnicamente pertrechado y objetivado en un aparato estatal de proyección universal, se refuerza además con otros elementos ideológicos excluyentes tales como el nacionalismo étnico en un caso, el determinismo histórico en el otro. "El nazismo» — apunta Gaos en este sentido- «es un régimen de vida pública, privada e íntima — hasta donde a éstas deja subsistir el régimen-, un régimen de vida total (...)», fundado en una supuesta ascendencia superior del pueblo alemán que, por su carácter «irrevocable» y «fatal», sustraído a toda voluntad, justifica e incluso hace necesario su dominio sobre los demás pueblos, los cuales nunca podrán ser considerados como iguales ni asimilados como «súbditos libres», tal y como sucede bajo la ideología imperialista clásica. Para Gaos, «en

67 Ibid., pp. 669s.

68 Ibid., p. 670. He apuntado y ampliado este punto en «José Gaos y la crítica de la técnica», en Sevilla, S.; Vázquez, M. E. (Eds.), Filosofía y vida. Debate sobre José Gaos, pp. 201-218. 
esta imposibilidad «de que el nazi considere como iguales a los miembros de otros pueblos radica el motivo decisivo para no poder tomar íntima y últimamente partido por el nazismo» ${ }^{69}$. Su "nacionalismo exclusivista» y racista cierra el paso a cualquier ideología universalista y le impide "verterse fuera de Alemania más que en la forma de una dominación sin posibilidad de incorporación de los dominados a los dominadores".

Un exclusivismo análogo, aunque algo más impreciso, aprecia Gaos en el caso del comunismo, en este caso de orden "clasista», en el sentido de que exige que quien no sea proletario de nacimiento abjure de su clase nativa y reconozca la superioridad del proletariado por la misión histórica que está llamado a realizar; algo imposible - prosigue Gaos_ a menos que se adopte «una concepción como la materialista de la historia», refutada en la actualidad por el «hecho de ser las clases medias en trance de proletarización la fuente primera y principal de las masas fachistas (sic) en todos los países ${ }^{70}$.

Pero para Gaos tampoco existen razones suficientes para tomar partido por «británicos y norteamericanos», aun a pesar de las bondades del liberalismo "relativamente a la vida pública de los individuos y a la independencia política de las naciones». Por desgracia — prosigue Gaos— éste es «conciliable superficialmente, aunque no lo sea sin inconsecuencia profunda, con el imperialismo relativamente a la economía y la cultura de los pueblos y su encarnación en la vida privada e íntima de los individuos». De ahí el legítimo recelo de los países iberoamericanos ante una victoria aliada, la cual se traduciría en «un reincremento del imperialismo dirigido desde Norteamérica (...), que bastaría fuese económico y cultural para constituir un peligro enorme contra la cultura de los países al sur del Bravo » ${ }^{71}$.

Esta triple y asfixiante beligerancia, la cual trataría como adversarios incluso a quienes la rechazaran y adoptaran una posición neutral, expresaría para Gaos la vigencia actual del totalitarismo y su radio de largo alcance, hasta el punto de solaparse con el paradigma liberal o de reconocerse sombríamente en algunas de sus señas geopolíticas de identidad: el estado liberal no puede ser totalitario en un sentido estricto, pero sí puede cumplir algunas de sus condiciones de posibilidad y universalizarlas en clave imperialista. No es equiparable a un estado policial y total, exclusivamente funcional e identificado con un partido oficial que absorbe y monopoliza opresivamente la acción política frente al resto de la sociedad; pero sí puede satisfacer sus dos grandes condiciones previas, a través de un imperialismo económico y cultural que ha dejado caducas las fórmulas asimiladoras del imperialismo clásico. Esas condiciones no son otras, precisamente, que la publicidad y la tecnocracia, rasgos esenciales del inminente capitalismo de masas que, si bien el enfoque gaosiano, más fenomenológico que crítico, nunca llegará a escrutar, sí señalará temprana y novedosamente en el contexto de la filosofía en lengua española.

69 «La situación actual de beligerancia forzosa», fóleo 921f.

$70 \quad$ Ibid., fóleo $921 \mathrm{~g}$.

71 «La situación actual de beligerancia forzosa», fóleo 921h. Como bien es sabido, la tesis del imperialismo colonialista como condición previa del totalitarismo, enraizado en la contradicción ente el sistema político del estado-nación y el desarrollo económico e industrial del último tercio del siglo XIX, será ampliamente desarrollada por Hanna Arendt en 1967, en el segundo volumen de Los orígenes del totalitarismo, si bien ciñéndose al contexto europeo. 
En definitiva, Gaos pone en juego dos acepciones de totalitarismo: una estricta o exclusivamente política y otra más amplia y difusa, que puede caracterizar, no sólo a los regímenes totalitarios convencionalmente identificados como tales, sino también al régimen de vida característico del estado liberal y capitalista. En ambos casos se cumple una doble condición de posibilidad: la publicidad o anulación de la intimidad de los sujetos y la tecnocracia o dominación organizada de la comunidad que conforman estos sujetos desposeídos de sí mismos.

Ahora bien, Gaos se pregunta además por los orígenes de la publicidad y la tecnocracia. O lo que es igual, plantea una genealogía del totalitarismo, lo que le lleva a retrotraerse nada menos que hasta la cristiandad medieval. Para Gaos, las raíces del totalitarismo se hunden en el proceso secularizador de la razón moderna y en su significación inmanente, entendida como progresiva sustitución de la religión por la filosofía y, simultáneamente, como reducción creciente de esta última a ciencia y técnica.

\section{De la CRÍtica DEL tOTALITARISMO A LA CRÍtica DE LA SECULARIZACióN}

El análisis gaosiano de la secularización, expuesto sobre todo en su Curso de metafísica de 1944, parte de una fenomenología de la vida cristiana —o católica, dirá en otros momentos, sin hacer explícitas las diferencias entre uno y otro término- en su expresión común o vulgar. De acuerdo con ella, Dios se hace presente a la persona recogida en su intimidad y en su condición radicalmente individual, en términos de salvación y bajo cinco caracteres: la experiencia de la propia vida o del mundo real como correlato de otra vida, trascendente y suprarracional; la índole imaginativa —-más que conceptual- de esa otra vida, en el sentido, no de que sea imaginaria, sino de que es «imaginada como real y verdadera»; su presencia, por tanto, no tanto «en el mundo» como en "la solitaria intimidad individual de la persona» (p.18); la índole «afectiva» (p.19) de esta presencia; y la experiencia de la muerte como el instante revelador de la misma. La progresiva disolución de esta presencia íntima y trascendente de Dios será precisamente el itinerario que recorra la razón moderna en su progresión inmanente, tecnificante y secularizadora, entendida tanto en términos fenomenológicos — desde las certezas irreflexivas que proporciona el catolicismo en su expresión tradicional hasta una depuración crítica, extrema y anuladora de las mismas-, como históricos — desde la cristiandad medieval hasta la crisis del momento presente y sus consumaciones totalitarias-. O, si se prefiere, del mito a la ilustración.

Gaos recorre este doble y complementario itinerario en el mencionado curso, poniendo el acento en la publicidad y en el enfoque fenomenológico a lo largo de la primera parte; en la técnica y en la perspectiva histórica, en la segunda. Respecto a lo primero, visualiza el paso del catolicismo al inmanentismo y la publicidad —y en definitiva, al totalitarismo- tomando como referencia ciertas experiencias humanas capitales, tales como la muerte y la sexualidad.

Fijémonos en la experiencia de la muerte. Para el católico — argüirá Gaos— vida en presencia de Dios y vida en presencia de la muerte «son una y la misma vida» (p. 55), en el sentido de que la muerte es el instante en que se consuma su relación 
de intimidad con el mundo trascendente que sirve de base a sus creencias. Por eso la «vida católica viene a ser, no simple espera, sino esperanza de la muerte», temor y al mismo tiempo expectativa de una «superación GOZOSA de ella» (p. 34). Muerte significa entonces «esperada llegada, perfección de la persona» (p. 38), "esencial destino y necesario advenimiento personales» (p. 99), Es la experiencia íntima, y por tanto intransferible, en que la vida culmina y se realiza plenamente, dotándola de un sentido. "La personalidad del católico no está, pues, íntegra, acabada, perfecta, mientras su muerte no viene a integrarla, acabarla, perfeccionarla» (p. 42). Su vida es un «bien morir» (p. 38) mientras su muerte "va viniendo y acaba por llegar» La eminencia, el sentido y la esperanza serían así rasgos primordiales de la muerte en la vida católica.

Pero hay otros rasgos que Gaos no deja de subrayar y que nos obligan a precisar y completar su fenomenología de la intimidad, la cual no se agota en la dimensión solitaria de la persona ni en su relación individual e intransferible con Dios. En el catolicismo, la muerte adviene siempre «en compañía»(p. 39), señala una trascendencia que congrega y genera una comunidad o una «comunión» esencial de vida "por la espera de la muerte». Cada una permanece unida a las demás «por el esperar cada una las mismas muertes, el tránsito de las mismas personas a lo trascendente» (p. 55). Todas ellas permanecen unidas "por la imaginación DEL otro mundo y LA otra vida (...)» (p. 99), o por obra «de esta relación de cada una con lo trascendente» (p. 55). Asimismo, se trata de una comunión de la que también forman parte los muertos, lo cual nos remite a otro rasgo de la experiencia católica de la muerte que Gaos tampoco escatima: el recuerdo de aquellos y su presencia entre los vivos, expresada a través del luto. Por medio de él, la muerte se hace presente en la vida pública, reforzando y enriqueciendo el vínculo comunitario entre los vivos.

Todo lo contrario sucede en la experiencia inmanentista de la muerte, la cual está ausente de la vida y es concebida, consecuentemente, como un «accidente impersonal» o como algo que sobreviene «inesencialmente, innecesariamente» (p. 36); que podría haberse evitado y transferido al prójimo, y que es fruto de la desventura o la desgracia. Por eso la muerte inmanentista es vivida conforme a la «psicología de los accidentados» (p. 42), aun cuando no se muera como consecuencia de un accidente, y por lo tanto «como todo menos como perfección de la persona». Tal es, para Gaos, el sinsentido que define a la experiencia de la muerte en nuestros días, cuyo anonimato se manifiesta además en sus espacios habituales: "clínicas, hospitales, en suma, establecimientos públicos e impersonales, donde se es una habitación, una cama, un número». Incluso cuando se muere en casa, "se muere como si se muriese en uno de dichos establecimientos», por la semejanza de «la arquitectura y hasta el amueblamiento y la decoración interior más reciente» (p. 43), y también porque se muere en medio «de artefactos técnicos» y de aparatos que han sustituido a los objetos personales del moribundo, desvinculado de su historia familiar y en una compañía lo más reducida posible, medida por «la medicina y los reglamentos» más que por «los afectos» (p. 44).

Asimismo, la accidentalidad, el anonimato y el asilamiento determinan todo vínculo colectivo ante la experiencia inmanentista de la muerte. Ésta no es, ya, un acontecimiento trascendente que, como tal, congrega en torno a sí a las distintas vidas que la esperan fecundando los lazos entre ellas, sino un hecho puramente 
fáctico y contingente, incapaz de generar otros vínculos que los meramente accidentales. "La muerte, concebida como impersonal accidente frustrador (...)», deja a los individuos «sin intimidad, sin vida privada, en perceptiva vida pública, en publicidad - y sin embargo, no en comunión, sino en sociedad o en comunidad totalitaria inmanentes (...)». (p. 101) Una comunidad que, consecuentemente, exige "una política sistemática de ocultación de la muerte y para BORRARLA», algo bien palpable en la sustitución de las capillas ardientes por las salas de las agencias funerarias y de las procesiones por el «transporte de cadáveres» — que Gaos no tiene reparo en comparar con «el transporte de carnes, del matadero a la carnicería ${ }^{72}$-, en la propia comercialización de la muerte a manos de dichas agencias, en la «rapidez y disimulo» (p. 53) con que se celebran los entierros en nuestros días, y, por supuesto, en el olvido de los muertos, a los que se declara inexistentes ${ }^{73}$. "La Humanidad» apunta Gaos a este respecto- "ha vivido tradicionalmente en convivencia con sus muertos. ¿Nos damos cuenta de lo que significa nuestra vida? Porque nosotros somos unos primeros humanos vivientes sin muertos». Gaos toca así, indirectamente, una cuestión de gran relevancia crítica como es la ausencia de memoria en la razón moderna y el olvido como condición de la lógica de progreso que recorre sus grandes construcciones. Gaos advierte que el inmanentismo moderno y sus modos totalitarios de vida guardan una estrecha relación con el olvido de los que mueren anónimamente y con disimulo, y de cuyos cuerpos se extraen beneficios industriales, si bien no llega a desarrollar el potencial crítico y anamnético de esta experiencia cotidiana de deshumanización. No obstante, en las líneas siguientes esboza una sugerente conexión entre el olvido, el exilio y la construcción moderna de la nación:

«El expulsar de la patria, el dejar sin patria, no a individuos más o menos numerosos, sino a masas enteras de compatriotas, que se ha generalizado en nuestros días, en fenómenos sin antecedente histórico desde la invasión de los bárbaros, ¿̇no se deberá a que los expulsores son impíos hombres de nuestros días, que no se sienten vinculados por los difuntos comunes a los compatriotas, ni obligados a retenerlos en el suelo patrio, aunque sea en civil contienda, pero en último trance en tierra patria?» (p. 54) $)^{74}$.

72 «Pero ¿es que de veras no han advertido ustedes el parecido escalofriante que hay entre los automóviles en que se transporta o se acompaña a los difuntos a los cementerios y los automóviles en que se reparte la carne —unos y otros en su misma arquitectura de armario o cajón, y sus laterales brillantes con el rótulo de la casa?» (pp. 52s).

73 En el fragmento 148 de Minima moralia (1951), titulado “Matadero", AdorNo se referirá a la experiencia actual de la muerte, reducida a una cuestión de higiene y de "recambio de funcionarios", a una exclusión irrelevante del ser natural de la trama social que previamente lo ha domesticado, o sencillamente, a una mentira. Bajo el capitalismo de masas, la muerte ha perdido el concepto de su dignidad, "no por el vigor de la esperanza en el más allá, sino por la desesperanzada falta de vigor del más acá.” Cf. Minima moralia. Versión castellana de Joaquín Chamorro Mielke. Taurus, Madrid, 1999, pp. 235 ss. Las descripciones de Gaos de la forma de vida propia del inmanentismo recuerdan en algún momento a la adorniana "frialdad burguesa".

${ }^{74}$ Muy poco tiempo después, en Pensamiento de lengua española, señalará GAos la vocación totalitaria del moderno Estado nacional, contraponiéndolo al Estado-ciudad de la antigüedad griega. Este último designaría una "comunidad cultural íntegra”, cuyos ámbitos, incluido el político, permanecían "unidos, más que diferenciados”. Su dislocación y autonomía de esta comunidad - prosigue Gaos - "es un proceso y una situación final característicos de la edad moderna, respondiendo al carácter más radical del hombre moderno. Por lo que se refiere singularmente a la forma política, al dilatarse la comunidad cultural de la ciudad a la nación, la forma política del 
La presencia íntima y trascendente de la muerte en la vida y la consecuente memoria de los muertos, constituiría así para Gaos una clave esencial para la construcción de una comunidad no excluyente. El cristianismo, idealmente, recoge y consigna esta presencia y esta memoria, si bien de una manera imaginativa e irreflexiva. El inmanentismo, como resultado de la progresión secularizadora de la razón moderna, elimina ambas depositando su centro de gravedad en la vida sola e intrascendente, lábil y superflua, «sin valor y sin sabor» (p.62), desposeída de su intimidad y abandonada, en consecuencia, al régimen publicitario del que se alimenta el totalitarismo. "Intimidad, individuación y sin embargo unión íntima y esencial, comunión, son el paradójico doble efecto de la trascendencia. Comunismo, totalitarismo, publicidad y sin embargo unión meramente accidental y por ello menos intima, son el paralelo doble correlato del inmanentismo» (p. 56).

Otra manera de visualizar el paso del catolicismo al inmanentismo es la retrospectiva histórica, que Gaos plantea en la segunda parte de su curso de 1944 subrayando la dimensión tecnificante de la secularización y su raíz afanosa e irracional. El afán de saber y — por medio de él- de poder, late bajo el despliegue de la filosofía moderna y encuentra precedentes en el seno mismo de la cristiandad medieval cuando persigue el entendimiento racional de lo ya sabido por la fe. Tal es, a juicio de Gaos, el gran hilo conductor del «racionalismo» tomista, el cual asienta las bases de la ulterior evolución secular de dicho entendimiento. Primero se despeja su superioridad e independencia frente al saber revelado sin menoscabo de su preeminencia-, hasta llegar a romper la comunidad de fe en que inicialmente se insertaba. Después se desprende de la tradición recibida de la Iglesia, en favor de la evidencia racional como condición de su propia certeza. En este sentido discurrirá la labor destructora y reconstructora de la razón moderna iniciada por Descartes y retomada por Kant, conforme a un inmanentismo creciente que, radicalizado, irá desnudando la índole, no ya subjetiva, sino también afectiva, impulsiva o infra-racional de dicha evidencia. La soberbia, el sentimiento de autosuficiencia y, en definitiva, el afán de dominación por medio de la razón - motivo que, por cierto, no deja de remitirnos a la asimilación gaosiana de Nietzsche-, es entonces el gran detonador del proceso inmanentista y secularizador de la modernidad: «la razón, la intuición filosófica no se sostiene en ella misma, sino en el sentimiento de su autosuficiencia absoluta; o en ella misma, si se considera que, en cuanto intuición afectiva, entraña tal sentimiento» (p. 172). Por eso el "paso del catolicismo al inmanentismo no se ha llevado a cabo (...) por razones racionales, sino por motivos irracionales, impulsivos». (p. 178) Por eso mismo, también, «lo moderno es la justificación de la impulsividad por la razón»(p. 175), más que una justificación de la razón por sí misma. Es esa impulsividad la que mediante la razón filosófica se ha emancipado de la religión y la que, modernamente, se reconoce como afán de y sobre su mundo, que no

\footnotetext{
Estado-ciudad quedó pequeña y se desprendió de contenido cultural. Es lo que trajo la depauperación semántica del término. El totalitarismo de nuestros días no representa ninguna rectificación. Todo lo contrario. Representa un extremo de lo anterior." Sólo a expensas de ese contenido cultural devorado "prolifera parásito y canceroso el Estado totalitario: todo y uno era allá la comunidad cultural, es acá el Estado." Cf. Obras completas VI, p. 70.
} 
es otro que el mundo inmanente de la naturaleza. Una vez consumada su emancipación de la religión, habrá de canalizarse entonces como «afán técnico, esto es, de manejo de la naturaleza física y de manejo similar de la naturaleza humana (...)». (p.176) La ciencia física de Galileo y la naturalización del hombre llevada a cabo "por el materialismo de Hobbes en el plano de la realidad»y "por el positivismo de Hume en el plano del conocimiento», dotarán de contenidos a este nuevo afán, inmanentista y moderno. Con Maquiavelo y Galileo — «mecánico», éste último, "de un príncipe que debía ser como el dibujado por aquél»—, con Hobbes y Hume - dirá Gaos más tarde, en su Historia de nuestra idea del mundo- emerge «una nueva variedad histórica de la especie o el género homo, el hombre moderno quien hace irrupción con su radical y esencial impulso y afán de poder y ahorro sobre el mundo natural y el humano — sin cuidarse del sobrenatural» ${ }^{75}$. La razón filosófica dejó así de ser «ancilla theologiae» para transformarse en "ancilla scientiae, es decir, de ancilla Dei pasó a ser ancilla hominis, de fámula de la trascendencia a fámula del inmanentismo... ${ }^{76} \mathrm{El}$ hombre moderno - dirá Gaos en otro texto inédito- «vive concentrado en esta vida y este mundo como si no hubiera otros, de donde la necesidad de llenar su vida por ideales y empresas del tipo de la dominación de la naturaleza por medio de la técnica. La tecnocracia se presenta aquí como el ideal inmanentista que sustituye a ideales trascendentes ${ }^{77}$.

Gaos aprecia esta sustitución en los tiempos totalitarios actuales incluso bajo una tendencia como el existencialismo. Con su consagración del «hecho puro, bruto, nudo» e "inesencial» de la existencia, flotante en medio de la nada y del no-ser, como residuo del proceso autodisolutivo de la razón moderna, el argumento genuino de la filosofía como tal — «lógon didónai»—, se esfuma bajo el afán instrumental de saber surgido de la conciencia científica moderna. Si tradicionalmente la filosofía ha sido «esencialismo» o búsqueda de una razón de ser encontrada «en las esencias y en última instancia en la divina», en el momento presente «esta razón consiste en afirmar en definitiva que ni siquiera tiene sentido la cuestión de la razón de ser, ni de la existencia, ni de la manera de ser esencial, ni de los demás seres, ni del ser humano mismo. (...) Todo se reduce, pues, a la existencia sin esencias». Si antaño la filosofía «era cosa última, o primeramente, de esencias», ahora lo es "exclusivamente de existencias» ${ }^{78}$. Esto es —prosigue Gaos- «lo que expresa o significa más extremadamente y más radicalmente el existencialismo de nuestros días», una incapacidad para dar razón, no ya de la existencia y de la manera de ser del hombre, sino también de la propia actividad filosófica como tal. La filosofía existencial es por ello «la filosofía irracionalista por excelencia ${ }^{79}$, expresando con ello la irracionalidad consumada a que ha abocado el afán técnico de la modernidad con su creciente hostilidad hacia las esencias y su consecuente substitución del conocimiento de los seres por el afán

75 Obras completas XIV, p. 447.

76 Curso de metafísica de 1944, p. 177.

77 Fragmento manuscrito. Fondo 1, carpeta 9B, fóleo 742j. Debo a Aurelia Valero Pie el conocimiento de este fragmento.

78 «La situación de la filosofía en el momento presente», Obras completas III, p. 262.

79 Ibid., p. 265. 
de dominarlos e instrumentalizarlos. Es decir, la progresiva naturalización de la filosofía consumada en la tecnocracia y el progresivo vaciamiento secular e inmanente del entramado de esencias que dotaban al mundo de consistencia ontológica son en realidad dos caras del mismo proceso. Si el existencialismo sólo puede surgir una vez que dicho afán ha desmitificado la ilusión de la permanencia o de un fundamento racional, la técnica sólo puede consumar su instrumentalización de la vida una vez que ésta ha sido reducida a existencia vacua. El totalitarismo será expresión de esta conjunción: «Lo que se ha llamado totalitarismo, ¿no se caracteriza al par por la voluntad de dominación sobre los seres humanos y por los fundamentos irracionales, como el vínculo de la sangre, hasta el extremo de no importarle tener razón?»80.

La transmutación totalitaria de la razón moderna en afán irracional e instrumental de dominación es en definitiva la manifestación extrema de la progresión secularizadora inscrita en la razón moderna. En sintonía con otras reflexiones exiliadas como las de Eugenio Ímaz y María Zambrano, aunque con acentos bien diferentes ${ }^{81}$, Gaos ubicará el fenómeno totalitario al término de un proceso marcado por el inmanentismo creciente del sujeto moderno y la consecuente abolición de la tensión entre razón y religión; o - dicho de otra manera- entre la negación de la religión en tanto que mito imposibilitador de la razón y su afirmación en tanto que humus del que esta última puede nutrirse secularmente. La abolición de esta tensión mediante la disolución afanosa e inmanente de la religión en la razón, a costa de despojar al sujeto de su intimidad, de reducirlo a su exterioridad o su dimensión pública y de instrumentalizarlo, desembocará en un retorno mítico de aquella. Por eso publicidad y tecnocracia significan «involucionismo»y "primitivismo» ${ }^{82}$, por eso el totalitarismo es mitificación de la razón y generación consecuente de nuevas religiones, puramente inmanentes y en definitiva políticas. «Nuevas religiones, en nuestros días políticas», anotaba Gaos en $1943^{83}$. "Lo político, como algo irracional» —escribía no mucho tiempo después— «ha sido erigido en "principio de vida" por el totalitarismo ${ }^{84}$.

\section{Pensar en español}

No deja de resultar muy pertinente - y hasta cierto punto, revelador- advertir la proximidad en el tiempo de estas reflexiones en torno al totalitarismo con aquellas otras que Gaos dedicara, con gran profusión, al pensamiento de lengua

$80 \quad$ Ibid., p. 263.

81 Me he aproximado a las reflexiones sobre el totalitarismo de estos dos autores en "El legado filosófico-político el exilio español del 39”, en Isegoría, 41 (2009), pp. 201-216; “Cultura y crítica al fascismo en el pensamiento exiliado español de 1939”, en Aguirre, A.; Santasilia, S. (Coords.), Pensar el mundo. Juventud, cultura y educación, Afinitá, México, 2010, pp. 48-68; "El pensamiento exiliado del 39 y la crítica del fascismo: Eugenio Ímaz y María Zambrano”, en CABAÑas Bravo, M. ; Fernandez Martinez, D. ; De Haro Garcia, N. ; Murga Castro, I. (Coords.), Analogías en el arte, la literatura y el pensamiento del exilio español de 1939, CSIC, Madrid, 2010, pp. 315-326.

82 Curso de metafísica de 1944, p. 96.

83 "Mi filosofía”, Obras completas III, p. 414.

84 “¿Son filosóficos nuestros días?”, Obras completas III, p. 247. 
española. Tal es el caso de su ya citado ensayo Pensamiento de lengua española (1947), y de sus antologías Pensamiento español (1945) ${ }^{85}$ y Antología del pensamiento de lengua española en la edad contemporánea $(1945)^{86}$. No mucho tiempo después, se publicaban sus volúmenes En torno a la filosofía mexicana (1952-53) y Filosofía mexicana de nuestros días (1954) ${ }^{87}$, sin olvidar los ensayos sobre Ortega y Gasset y otros autores españoles e iberoamericanos que conforman el volumen IX de sus Obras completas, y que fueron escritos durante las décadas de los cuarenta y los cincuenta ${ }^{88}$.

Esta proximidad no es nada casual. El interés de Gaos por el pensamiento de lengua española, que con tanta energía y éxito desarrolló sobre todo durante la primera etapa de su exilio, no sólo obedecerá a un ajuste de cuentas con el eurocentrismo de la razón moderna o con la historia de las ideas - dicho de otra manera, a una justa rehabilitación de dicho pensamiento en el contexto de la modernidad occidental, previo rescate de sus episodios y tendencias fundamentales-; a una prolongación crítica de la filosofía de la cultura que Ortega había programado en sus Meditaciones del Quijote, a propósito del «logos del Manzanares», o a la coyuntura intelectual y académica de su nuevo destino mexicano. También obedecerá a la búsqueda de respuestas que exige la situación de fracaso y punto muerto a la que ha llegado esa misma razón moderna, y ante la que la rica y velada tradición iberoamericana podría ofrecer un nuevo concepto de pensar, sin derivas totalitarias. En sintonía, de nuevo, con otros compañeros de exilio ${ }^{89}$, Gaos rastreará en dicha tradición otras maneras de entender la racionalidad, siempre desplazadas por los desarrollos canónicos y las objetivaciones científico-instrumentales de la filosofía moderna.

Bien es cierto que en estos escritos gaosianos sobre pensamiento de lengua española, el totalitarismo y su semántica permanece en estado latente, oculto y casi ausente. Por eso en ellos el clima de frustración que envuelve actualmente a la filosofía como tal se explica sobre todo en función de la contradicción entre unas filosofías y otras, sobre la que Gaos reflexiona a partir de una crítica tan liviana como la de Dilthey, de la misma manera que el pensamiento de lengua española encontrará su perfil más genuino en su condición estética y político-pedagógica, ligadas la expresión literaria y a una función ideológica explícita ${ }^{90}$. Pero, si tenemos en cuenta el contexto gaosiano de estos escritos en toda su amplitud y registramos la relevancia que en él adquiere el totalitarismo, nuestra perspectiva gana en profundidad. Pensar en español no sólo significará entonces reivindicar o justificar un

85 Cf. la segunda parte de Obras completas VI.

86 Cf. Obras completas $V$.

87 Cf. Obras completas VIII. Filosofía mexicana de nuestros días. En torno a la filosofía mexicana. Sobre la filosofía y la cultura en México. Prólogo de Leopoldo Zea. UNAM, México, 1996.

88 Cf. Obras completas IX. Sobre Ortega y Gasset y otros trabajos de historia de las ideas en España y la América española. Prólogo de Octavio Castro. UNAM, México, 1992.

89 Lo he expuesto sucintamente en "El exilio del 39 y su contribución a la reflexión sobre la filosofía en lengua española”, en Revista de Hispanismo Filosófico, 14 (2009), pp. 129-139; "Epígonos de una Modernidad exiliada: Gaos, Nicol, Xirau, Zambrano”, en SÁnchez Cuervo, A.; Zermeño Padilla, G. (Eds.), El exilio español del 39 en México, pp. 211-232.

90 Cf. por ejemplo, "El pensamiento hispano-americano. Notas para una interpretación histórico-filosófica”, Obras completas VI, pp. 31-110. 
pensamiento más flexible y expresivo, mayormente ligado al ensayo y dotado de una prosa más rica, tal y como tantas veces se ha repetido. Significará también algo más, como es la puesta en juego de respuestas a la deshumanización inscrita en el despliegue secular de la razón moderna y sus derivas irracionalistas y totalitarias, hasta el punto de alumbrar una nueva manera de pensar. En la última lección de su Curso de metafísica de 1944, tras dedicar, a lo largo del mismo, amplios análisis a la cuestión del inmanentismo, la publicidad, la tecnocracia y el totalitarismo, escribe lo siguiente:

«Pretender salirse de la tradición de la filosofía moderna sería ambición excesiva, al menos para mí: añadir a esta tradición pequeño enriquecimiento ya sería bastante, sobre todo si se debiese a la aportación de experiencias, y de los correspondientes conceptos de casta tan nueva en la filosofía moderna como sería la hispánica. Ahora bien, estoy convencido de que los hombres de la casta hispánica contamos con experiencias inéditas para la historia de la filosofía. Tal es la motivación metafísica, me atrevo a emplear el tremendo vocablo sin que me treme la voz, de mi interés creciente por el pensamiento de nuestra lengua, esto es, por las experiencias vitales, humanas, que históricamente lo originan» (p. 184).

Asimismo, en un fragmento sin fecha aunque probablemente de esos mismos años, escribe: «la posición española debe ser no la aceptación acrítica de la modernidad, sino la crítica de ella; no la aceptación acrítica de la filosofía como método de la modernidad, sino la crítica de tal método» ${ }^{91}$.

Obviamente, esto no significa que Gaos abogue por la restauración de ninguna servidumbre teológica o por el remozamiento de concepciones teocráticas del mundo, que se deslice hacia posturas anti-ilustradas o reaccionarias - lo cual también supondría una ruptura de la tensión entre razón y religión, de signo contrario al arriba señalado-, o que establezca una conexión esencial entre la secularización y el totalitarismo. Significa rastrear en el pensamiento de lengua española cómo se han elaborado conceptos como el de sujeto o el de intimidad, cuál ha sido la significación de sus impregnaciones religiosas —más allá, obviamente, de sus expresiones autoritarias y reaccionarias—, y cuáles han sido las causas o los motivos de su resistencia a la racionalidad tecno-científica dominante -más allá, asimismo, del tópico autocomplaciente que explica dicha resistencia a partir de la precariedad de las ilustraciones en el mundo hispánico-. Significa, en definitiva, tantear en dicho pensamiento la hipótesis de un despliegue secular no condenado a la irracionalidad o a la mitificación de la razón.

El propio Gaos constituye un exponente actual de este pensamiento y no parece que le falte conciencia de ello. Su reflexión sobre el totalitarismo, sobre su vigencia actual, sus expresiones y sus fuentes modernas forma parte, en este sentido, del «humus» en el que se irá madurando su propia filosofía, que no en vano es una «filosofía de la filosofía» o una tentativa de rehacer la experiencia racional del mundo sobre las ruinas de su arquitectura moderna y a partir de un afán de saber no violento. Pero una tentativa en lengua española: «La filosofía de la filosofía como

91 Fragmento manuscrito. Fondo 1, carpeta 42 B, fóleo 7556. Otros fragmentos de esta misma carpeta aparecen fechados en 1943-44. Debo a Aurelia Valero Pie el conocimiento de este texto. 
revisión crítica de la filosofía en mí» —escribía en sus notas de 1943- «resulta una revisión (Historia) crítica de la historia (esencial) del Occidente moderno desde un punto de vista español» ${ }^{92}$

Instituto de Filosofía

Antolín Sánchez Cuervo

Consejo Superior de Investigaciones Científicas

(Madrid)

antolin.scuervo@cchs.csic.es

[Artículo aprobado para publicación en diciembre de 2015]

92 «Mi filosofía», Obras completas III, p. 406. 